\title{
Perceived strategic implication of solid waste recycling across Malaysian higher education institutions
}

\author{
Mohamad Rizal Baharum ${ }^{1 a}$, Hui Wen Kam² and Shirley Jin Lin Chua ${ }^{3}$ \\ 1amrizal@um.edu.my, ${ }^{2}$ bha110015@siswa.um.edu.my, ${ }^{3}$ shirleychua88@um.edu.my \\ 1,2,3 Department of Building Surveying, Faculty of Built Environment, University of Malaysia, 50603 Kuala Lumpur, Malaysia.
}

\begin{abstract}
Sustainability of higher education institution campuses is the main concern in the institution sector worldwide. In achieving sustainability, strategic management such as planning, implementation and strategic implication of recycling initiatives became an essential criterion. This paper aimed to investigate the strategic implication achieved between higher education institution groupings. Questionnaire survey was conducted and completed by 129 institutions in Malaysia. The significance of strategic implication variables was identified through ranking analysis. An ANOVA analysis was conducted to identify the variation in effectiveness level of the overall strategic impacts across higher education institution groups. The findings revealed that the significant differences in effectiveness level of overall strategic impact occurred between the perception of private university and college. The implication of the results was discussed with regard to strategic impacts of solid waste recycling which is useful in the strategic planning of institutions' recycling initiatives.
\end{abstract}

Keywords: Malaysia, higher education institutions, strategic implication, solid waste recycling

\section{Introduction}

Sustainable development is the main issue in worldwide. Many declarations such as Rio declaration of Rio Earth Summit (1992), Kyoto Declaration (1990), Agenda 21 (1992), Thessalaniki Declaration (1997), and Rio+20 reveal that the increasing important of environmental concerns in all sectors. Rapid industrialisation and economic development has caused vast increase of solid waste generated [1]. Landfill method is always the general method used to dispose the solid waste in most of the developing countries, which include Malaysia. Past studies [2-4] also found that landfill is a common method utilised in disposing solid wastes in Malaysia where most of the landfill sites are open dumping sites.

The plea for sustainable recycling in developing countries has widely been recognised in many scholars [5-8]. However, previous studies $[9-15,1,16]$ mostly concentrated the studies on municipal wastes. Albeit few past researches [17-18] were focused on institution wastes but they only conducted their research on particular university [17], not researched on entire higher education institution sector.

Higher education institutions are similar to large commercial concerns because of their (staffs and students) waste production and consumption of energy and materials [19]. Previous studies [20-22] confirmed that folks with higher education are expected to be more aware of environmental problems which would advocate them to recycle. Hence, a research regarding solid waste recycling on Malaysian higher education institutions was required to investigate the current implementation of solid waste recycling in the institutions.

\section{Strategic implication}

Strategic management is defined as the art and science of establishing, conducting and assessing crossfunctional decisions that will permit an organisation to achieve its objectives [23]. While strategic planning is very important to increase the delivery of recycling performance to accomplish sustainable development and to strengthen long-term growth [24]. The concept of converting wastes into valuable monetary capitals, environmental and social revenues [25] has attained interest as a means of protecting environment because it provides one of the most viable solutions both costeffectively and ecologically for administering waste [26]. Definitely, recycling conserves natural resources, consumes less manufacturing energy, reduces total disposed waste volume, lessen demand for virgin materials, minimises environmental and economic costs, and health as well as environmental risks [27-30].

\footnotetext{
${ }^{a}$ Corresponding author: mrizal@um.edu.my
} 
Overall, five main strategic variables in the aspect of environment, economic, social and legal were identified and discussed in following sections.

\subsection{Waste stream minimisation}

Most of the recycling initiatives embarked were aimed for the environmental sustainability as a priority. A variety of benefits aroused from waste minimisation in business were identified in [31]'s study. The benefits consisted of increased profits, competitiveness, enhanced management control and corporate image. Besides, recycling generates employment and attracts investments [32-33]. The most obvious result of waste reduction can be seen through composting programmes [34]. Composting programme was deemed as successful initiative in wastes reduction since a composting programme carried out by a city council found that most of the households recorded between $40 \%-60 \%$ of reduction in solid waste amount for disposal which at the same time reducing the money spent on waste management [35]. Therefore, a waste manager or facilities manager shall put the achievement of waste stream minimisation as foremost aim in their solid waste recycling planning.

\subsection{Cost reduction}

One of the critical challenges with developing sustainable waste management system is the cost of implementation [36]. In commercial and business sector, cost reduction and profit generated is the first matter to look into when measuring the strategic implication. Several past researches proved the cost decrease on municipal solid waste management. For instances, the study conducted by [37] who examined the costs of municipal solid waste services and researched economies of scope and then concluded that there were cost savings from providing cooperative disposal and recycling services. Another research carried out by [38] found that recycling could reduce costs to the municipality for the solid waste collection and disposal by reducing the waste volume that the municipality deliver to its landfill. Besides, [39] researched on municipal solid waste recycling in Portugal found that incineration inclines to minimise costs by about $15 \%$. Another study on animal wastes recycling also found the reduction of the raw materials cost used in manufacturing fertilizers [40]. As majority of the previous researches were on municipal solid waste recycling, thus it is vitally important to study solid waste recycling in other sectors such as higher education institutions; for instance to find out to what extent they are managing their solid waste recycling.

\subsection{Revenue generated}

Strengthening recycling programmes is not only extended the life span of landfill, it also sustains the economy as recycling provides widely lucrative business ventures opportunities [1]. Recycling initiatives such as incinerations, composting and waste collection are successfully brought additional incomes for the companies/business and waste collectors. For instance, [41] found that in the methods of waste recovery, incinerators could generate electricity to sell to power enterprises and then earn substantial extra incomes for the company. Besides, [40] researched on zinc waste found out that zinc producer made revenues by selling zinc waste and it was also reducing costs of waste disposal. [40] in their study also found that the job of waste picking for recycling constitutes a source of income for many impoverished residents in Brazil. However the institution solid waste recycling was still considered at its infancy since no significant recycling performance in higher education isntitutions, thus whether the current recycling programmes have brought extra income for the institutions is still questionable.

\subsection{Change of recycling behaviour/culture}

The escalating rate of solid wastes in Malaysia has manifested from the change of consumption customs among Malaysian, as their per-capita income has increased throughout the years, where they can afford for more consumers than before [42] along with the rapid population growth and also urbanisation [43]. Few scholars argued that inconvenience of recycling facilities is a key influence on one's recycling behaviour, who further mentioned that such concerns appeared to outweigh attitudes about the lasting importance of recycling behaviour [44-46]. Sustainability awareness is portion of community behavioural change. An investigation shown that there was an association of recycling behaviour between the participation of non-profit organisations, newspaper reading, politics and religious activities [29]. To become sustainable, extraordinary change to behaviour is necessity.

\subsection{Compliance of Acts}

Regulation is essential to ensure quality and efficiency profits [47]. Enhanced environmental protection through the optimisation of waste management practices is the typical focal point of waste management polices and technologies in countries where powerful legislation has been well formulated and immediate health concerns have been controlled [48-49]. In developed countries, the European Union (EU) directives enforced by EU towards its member states is effective as the recycling rate achieved by those developed countries is high.

Focusing in Malaysia, there is no specific measure in the aspect of waste minimisation and recycling [1]; the function of solid waste management is generally carried out together with other associated functions for instances public area cleansing, street-light and drainage maintenance and landscaping. Solid Waste and Public Cleansing Management (SWPCM) Act 2007 (Act 672) is the sole regulation which established for solid waste management purpose in all sectors. Under the Act, the 
manufacturers, importers, or dealers have the obligation to recycle their products under Clause 102(1). However, [1] argued that even though the enactment of the SWPCM Act 2007 has given legislative empowerment to the Malaysian government and framework for the solid waste management, it cannot be enforced and implemented absolutely due to the lacking of other supporting regulations. [1] further elaborated that policy implementation could only be executed informally and in an ad-hoc practice by stakeholders. Although mandatory recycling which commenced in September 2015 , this is not explicit that this will resolve the issue and it does not include commercial and institution sectors. It is noted that strong legislations are definitely required; the cooperation from each organisation is also needed for the enforcement of the legislations.

\section{Malaysian higher education institutions}

Higher education institutions portray a multi-faceted role within regional economies and are of key importance in the knowledge creation and transfer worldwide via teaching, research and other activities [50]. Additionally, universities have the potential of teaching environmental literacy to the politicians, teachers, and decision-makers of tomorrow [51]. The past studies [20-22] found that folks with higher education were expected to be more aware of environmental problems which would encourage them to recycle. [52] concurred that higher education institutions could educate and demonstrate the principles of awareness and stewardship of the natural world, increased the chances of clean and pleasurable local and universal environments for the future.

Basically, Malaysian higher education institutions are categorised as public university, private university and college. According to the [53], total population of registered higher education institutions in Malaysia comprise 20 public universities, 71 private universities and 326 colleges. The type of premises of the higher education institutions are not taken into account for this study, as not all the higher education institutions have possessed property for their campus. Most of the public universities have owned their campus whereas majority of the private universities only held a lease on a premises for their campus. This is similar with colleges as most of the colleges are small institutions and do not possess property for their campus.

\section{Methods}

This study adopted a quantitative method by distributing questionnaire survey to the targeted respondents. Survey research provided a numeric description of trends or opinions of a population by studying a sample of that population [54]. Furthermore, this study employed cross-sectional study that applied questionnaire for data collection, with the intent of generalising from a sample to a population.
Simple random sampling method was chosen for the questionnaire survey in this study where all the subjects in the sample have a change of being selected in the research population. This sampling procedure would able to make sure every subject has the equal chance to be selected [55]. The targeted respondents to answer the questionnaire questions were the person who responsible for solid waste management and recycling initiatives in their respective institution. The study covers all the Malaysian higher education institutions with total population of 417 institutions format. Therefore, questionnaires were sent to all the higher education institutions which registered with the Department of Higher Education (formerly known as Ministry of Higher Education) in Malaysia. As a result of the questionnaire survey, a total of 129 sets of questionnaire were returned which gave a response rate of $30.9 \%$ (as illustrated in Table 1). Based on the data obtained, some of the respondents, included in the category of "other", were either landscape architects, executives, engineers, principal or senior manager. $85.3 \%$ of the respondents were director or manager of department/unit, facilities/operation manager and assistant manager (as shown in Figure 1). They are appreciably expert in the planning and implementation of institution solid waste recycling strategies. In addition, the respondents also involved in waste management on day-to-day basis; and therefore the responses on the questionnaire are reliable.

Table 1: Number of return questionnaires based on Malaysian higher education institution schemes [53]

\begin{tabular}{|l|l|l|l|}
\hline $\begin{array}{l}\text { Ownership } \\
\text { of } \\
\text { Malaysian } \\
\text { higher } \\
\text { eduations }\end{array}$ & $\begin{array}{l}\text { Malaysian } \\
\text { higher } \\
\text { education } \\
\text { institution } \\
\text { groups }\end{array}$ & Population & $\begin{array}{l}\text { Respond } \\
\text { ed }\end{array}$ \\
\hline Public & $\begin{array}{l}\text { Public } \\
\text { university }\end{array}$ & 20 & 13 \\
\hline Private & $\begin{array}{l}\text { Private } \\
\text { university }\end{array}$ & 71 & 35 \\
\cline { 2 - 4 } College & 326 & 81 \\
\hline Total & & $\mathbf{4 1 7}$ & $\mathbf{1 2 9}$ \\
\hline
\end{tabular}

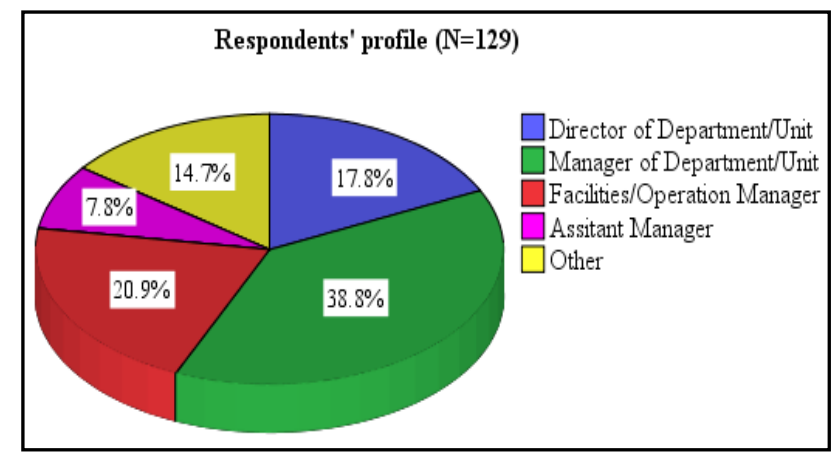

Figure 1: Respondents' profile

Before the questionnaires were entered into the database, all of the questionnaires were examined to ensure that they were valid for the research. The results obtained in questionnaire survey were then analysed 
through Statistical Package for the Social Science (SPSS) software. Reliability analysis was carried out for the strategic impact variables to enhance the reliability of the data. This analysis also can determined the possible accuracy of the measurements [56]. Cronbach's alpha test showed a coefficient of 0.871 which was considered satisfactory as [57] mentioned that the instrument with its alpha value between 0.65 and 0.95 was considered reliable.

Besides, mean and standard deviation were used in measuring the variables in ranking analysis. The mean score was used to rank the effectiveness level of the strategic variables. The main purpose of this ranking analysis was to indicate the difference in the level of effectiveness among the variables.

To test for the existence between two groups of significant differences with respect to higher education institution groupings and strategic impact variables, analysis of variance (ANOVA) was used.. ANOVA is a hypothesis testing procedure applied to compare the mean difference between two or more groups [2]. Thus, a hypothesis was developed:

$\mathbf{H}_{\mathbf{0}}$ : There are no differences of the mean scores of strategic implication effectiveness level across three groups of higher education institutions.

$\mathbf{H}_{1}$ : There are differences of the mean scores of strategic implication effectiveness level across three groups of higher education institutions.

Respondents were asked to rate their effectiveness level of strategic implication variables listed on a fivepoint Likert scale $(1-$ not effective, 5 - extremely effective). All five (5) strategic implication variables were grouped as a composite variable for overall effectiveness level of strategic implication variables. Composite variable could be defined by the following equation:

Strategic impact variable $(S I)=$

$(S I 1+S I 2+S I 3+S I 4+S I 5) / 5=$ mean score.

In this case, significance value determined whether the null hypothesis has to be rejected or not. ANOVA involved the calculation of $\mathrm{F}$, which compares the between-groups variance with the within-groups variance. And p-value (significance level) of $\mathrm{F}$ is also calculated [58]. The probability level of 0.05 is normally an accepting level for the scholarly journals [2]. When p-value is less than 0.05 , then null hypothesis is rejected and the groups are statistically different [58]. A normality test was carried out before the ANOVA test analysis. The data was normally distributed because both the skewness (.134) and kurtosis (-.893) values were within the normal distribution range.

\section{Results and discussions}

Results showed that the strategic impacts vary considerably in ranking with regards to its effectiveness level (Table 2). The mean score (with 1 - very low degree to 5 - very high degree) was applied to rank the level of effectiveness of the strategic impact variables. Based on the result from Table 2, mean score of the effectiveness of all Malaysian higher education institutions strategic impact variables were highly low and all were below 4.00 value of mean score. This shows that performance of solid waste management and recycling programmes in higher education institutions were not achieved the satisfactory level. This was most likely because solid waste management in Malaysia is still in operation level, most of the higher education institutions conducted recycling activities based on their voluntary initiatives and contributions.

However, compliance of Acts variable was ranked the most effectiveness among the five strategic impact variables, with 3.21 value of mean score; thus indicated its significance in solid waste recycling. Although the variable achieved the highest ranking of effectiveness level, the existing legislations in Malaysia are not comprehensive and still have loopholes on solid waste management in all sectors. Additionally, the existing waste-related Acts in Malaysia only make mandatory for institution organisations to dispose their waste in proper places. A new policy of mandatory of waste separation is imposed since September 2015, however the policy is only enforced on household in certain states. It is not a comprehensive policy because it is not imposed on all sectors and states. Additionally, no any recycling goal or target is required or imposed on higher education institutions. Hence, compliance of existing Acts is deemed to be achieved readily compare to another four variables due to the weaknesses of the existing policies.

Table 2: Ranking of institution strategic impacts towards solid waste recycling

\begin{tabular}{|l|l|l|l|}
\hline Ranking & $\begin{array}{l}\text { Strategic impact } \\
\text { variable }\end{array}$ & Mean & $\begin{array}{l}\text { Std. } \\
\text { Deviation }\end{array}$ \\
\hline 1 & Compliance of Acts & 3.21 & 1.021 \\
\hline 2 & $\begin{array}{l}\text { Waste stream } \\
\text { reduction/Waste } \\
\text { minimisation }\end{array}$ & 2.53 & 0.969 \\
\hline 3 & Cost reduction & 2.51 & 1.039 \\
\hline 4 & $\begin{array}{l}\text { Change of recycling } \\
\text { behaviour/culture }\end{array}$ & 2.41 & 0.973 \\
\hline 5 & Revenue generated & 1.84 & .837 \\
\hline
\end{tabular}

Waste stream reduction / waste minimisation variable was ranked as second highest of effectiveness level. This may because the government's primary aim and drive of recycling initiatives advocated is sustainable environment. Many recycling programmes are embarked with goals of sustainable environment by reducing the wastes, especially for composting programmes. There was a significant waste reduction at source through composting [34]. A home composting programme conducted by Petaling Jaya City Council, Malaysia found $40 \%-60 \%$ of reduction in solid waste volume [35]. Based around the results on Table 2, strategic impact variables such as cost reduction and change of recycling behaviour/culture were deemed as less effective variables. While revenue generated was ranked as the least effective variable. This was most likely because the recycling programmes initiated by 
public sectors were mostly aimed to reduce wastes. In contrast, the wastes which recycled by some industries exclusively meets the demands of economic production chains of the sector but not of importance to environmental management [59]. However in this juncture, recycling initiatives are still ignored by most of the private sectors as there is no mandatory policy imposed on them. However, in general, all strategic impacts are considered as critical in the way of attaining sustainability in solid waste management perspective after reviewing the literatures globally.

Although the effectiveness level of all strategic impact variables are ranked low, these five variables are believed as crucial based on the global literature reviews. Hence all five variables were then combined as a composite variable to analyse the overall performance of solid waste recycling at different higher education institutions. Similar procedure was applied by [60] in the study of shopping centre recycling success. The results of the ANOVA method were given in Table 3 . From the result, the value of $\mathrm{F}(\mathrm{df}=2,126, \mathrm{p}<0.05)=$ 5.1 was significant. As a consequence, null hypothesis was rejected and alternative hypothesis was accepted. This analysis performed that there were significant differences in the level of effectiveness of strategic impact variables among higher education institution groupings.

Table 3: ANOVA study result

\section{ANOVA}

Strategic implication

\begin{tabular}{|l|l|l|l|l|l|}
\hline & $\begin{array}{l}\text { Sum of } \\
\text { Squares }\end{array}$ & df & $\begin{array}{l}\text { Mean } \\
\text { Square }\end{array}$ & F & Sig. \\
\hline Between Groups & 5.154 & 2 & 2.577 & 5.114 & .007 \\
Within Groups & 63.495 & 126 & .504 & & \\
Total & 68.650 & 128 & & & \\
\hline
\end{tabular}

A post hoc test was used to compare the means of the respondent groups since the results obtained from ANOVA test did not point out the actual point of variation or how these factors were differed. Result from the post hoc comparison showed statistically significant variation was found, as illustrated in Table 4.

Table 4: Post hoc result with equal variances assumed (Tukey HSD) test

\section{Multiple Comparisons}

Strategic implication

Tukey HSD

\begin{tabular}{|c|c|c|c|c|c|c|}
\hline \multirow{2}{*}{$\begin{array}{l}\text { (I) } \\
\text { Institution } \\
\text { groups }\end{array}$} & \multirow{2}{*}{$\begin{array}{l}(\mathrm{J}) \\
\text { Institution } \\
\text { groups }\end{array}$} & \multirow{2}{*}{$\begin{array}{l}\text { Mean } \\
\text { Differen } \\
\text { ce }(\mathrm{I}-\mathrm{J})\end{array}$} & \multirow[b]{2}{*}{$\begin{array}{l}\text { Std. } \\
\text { Error }\end{array}$} & \multirow[b]{2}{*}{ Sig. } & \multicolumn{2}{|c|}{$\begin{array}{l}95 \% \\
\text { Confidence } \\
\text { Interval }\end{array}$} \\
\hline & & & & & $\begin{array}{l}\text { Lower } \\
\text { Bound }\end{array}$ & $\begin{array}{l}\text { Upper } \\
\text { Bound }\end{array}$ \\
\hline \multirow[t]{2}{*}{$\begin{array}{l}\text { Public } \\
\text { university }\end{array}$} & $\begin{array}{l}\text { Private } \\
\text { university }\end{array}$ & -.04835 & .23057 & .976 & -.5952 & .4985 \\
\hline & College & .37740 & .21210 & .181 & -.1256 & .8804 \\
\hline
\end{tabular}

\begin{tabular}{|ll|l|l|l|l|l|}
\hline $\begin{array}{l}\text { Private } \\
\text { university }\end{array}$ & $\begin{array}{l}\text { Public } \\
\text { university } \\
\text { College }\end{array}$ & .04835 & .23057 & .976 & -.4985 & .5952 \\
\hline College & $\begin{array}{l}\text { Public } \\
\text { university }\end{array}$ & -.37740 & .21210 & .181 & -.8804 & .1256 \\
& $\begin{array}{l}\text { Private } \\
\text { university }\end{array}$ & $-.42575^{*}$ & .14359 & .010 & -.7663 & -.0852 \\
\hline
\end{tabular}

*. The mean difference is significant at the 0.05 level.

Only the significance value ( $\mathrm{p}$-value) for the pair of private university and college was less than 0.05 , and was statistically significant. This revealed that the effectiveness level of strategic impacts was considerably difference between private university and college even though both are from private sector. This comparison test also showed that strategic impacts perceived by colleges were not as effective compared to other two institutions groups. This may because universities are equivalent to huge commercial with regard to their larger quantities of wastes generated [19] Additionally, universities also have more diverse programmes and activities than colleges because of the larger number of enrolled students. Hence, many initiatives are expected to be conducted to deal with the large quantities of wastes. Besides, universities have larger scale of organisation whereas colleges have smaller scale of organisation. Colleges may not have sufficient basic facilities and human resource to conduct recycling since they are only a small organisation. Hence, it is expected that colleges performed less effective in the operation of solid waste recycling.

\section{Conclusion and implication}

This is important to underline that this article does not provide the methods to attain the strategic implication on solid waste recycling; it is an analysis of variance applied to an overall strategic implication of solid waste recycling in order to increase knowledge about the strategic impacts towards higher education institution solid waste management. The global literature review revealed five strategic impact variables which are significant in solid waste recycling operation. Ranking analysis showed that Compliance of Acts was perceived as the most effectiveness for institution solid waste recycling. However in fact, review of waste-related legislation is imperative. The results obtained from analysis of variance found the significant difference on effectiveness level of strategic impacts between private university and college. The higher education institutions could introduce some effective recycling initiatives and also formulate mechanisms to increase the likelihood to achieve strategic impacts. The mandatory policy of waste separation would be the main initiative that must be considered to increase the recycling performance as this is in conjunction with the national policy that mandate households to conduct waste separation in their home. Despite the findings generated by the present study, future research is required to study in detail to what extent the difference of the solid waste recycling 
management between the university and college. Besides, a national study should be designed on strategic solid waste management in higher education institution to effectively increase its recycling performance. The results obtained from a national study would provide important implications for waste planning, policy making and transition to sustainable waste management for higher education institutions.

\section{References}

1. Y. C. Moh, L. Abd Manaf. Overview of household solid waste recycling policy status and challenges in Malaysia. Resour. Conserv. Recycl. 82(0), 50-61 (2014).

2. M. N. Latifah, A. M. Derus, S. Wok, Z. Hamid, Statistics made simple (2nd ed.). Kuala Lumpur: Malaysia: Research Centre International Islamic University Malaysia (2004).

3. M. N. M. Yunus, K. A. Kadir, The development of solid waste treatment technology based on refuse derived fuel and biogasification integration. In: International Symposium on Renewable Energy. Kuala Lumpur, 14-17 September 2003 (2003).

4. The Ingenieur. Sanitary landfill: a strategic approach towards solid waste management. Boards of Eng. Malaysia (BEM) 42, 12-16 (2009).

5. P. J. van Beukering, M. N. Bouman, Empirical evidence on recycling and trade of paper and lead in developed and developing countries. World Development 29(10), 1717-1731 (2001).

6. D. C. Wilson, C. Velis, C. Cheeseman, Role of informal sector recycling in waste management in developing countries. Habitat Int. 30(4), 797-808 (2006).

7. S. Suttibak, V. Nitivattananon, Assessment of factors influencing the performance of solid waste recycling programs. Resour. Conserv. Recycl. 53(1-2), 45-56 (2008).

8. A. M. Troschinetz, J. R. Mihelcic, Sustainable recycling of municipal solid waste in developing countries. Waste Manage. 29(2), 915-923 (2009).

9. M. H. Isa, F. A. H. Asaari, N. A. Ramli, S. Ahmad, S. S. Tan, Solid waste collection and recycling in Nibong Tebal, Penang, Malaysia: A case study. Waste Manage. Res. 23(6), 565-570 (2005).

10. W. Murad, C. Siwar, Waste management and recycling practices of the urban poor: A case study in Kuala Lumpur city, Malaysia. Waste Manage. Res. 25(1), 3-13 (2007).

11. M. O. Saeed, M. N. Hassan, M. A. Mujeebu, Assessment of municipal solid waste generation and recyclable materials potential in Kuala Lumpur, Malaysia. Waste Manage. 29(7), 2209-2213 (2009).

12. MHLG. Composting- closing the loop at home: $A$ household home composting programme in Majlis Bandaraya Petaling Jaya (MBPJ). Retrieved on 21 June, $2013 \quad$ from http://www.kpkt.gov.my/jpspn/main.php?Content= articles\&ArticleID=50\&IID= (2010).

13. P. Agamuthu, S. Chenayah, S. H. Fauziah, D. Victor, 3R Related Policies for Sustainable Waste
Management in Malaysia. Paper presented at the Innovation and Sustainability Transitions in Asia, Kuala Lumpur, Malaysia (2011).

14. R. Afroz, M. M. Masud, R. Akhtar, J. B. Duasa, Survey and analysis of public knowledge, awareness and willingness to pay in Kuala Lumpur, Malaysia - a case study on household WEEE management. J. Clean. Prod. 52(0), 185-193 (2013).

15. I. S. Zen, Z. Z. Noor, R. O. Yusuf, The profiles of household solid waste recyclers and non-recyclers in Kuala Lumpur, Malaysia. Habitat Int. 42(0), 8389 (2014).

16. A. M. Akil, J. Foziah, C. S. Ho, The Effects of Socio-Economic Influences on Households Recycling Behaviour in Iskandar Malaysia. Procedia - Social and Behavioral Sci. 202, 124-134 (2015).

17. R. Elfithri, T. K. Ghee, N. E. A. Basri, S. M. Zain, Integrated Paper Recycling Management System in UKM Campus. Procedia - Social and Behavioral Sci. 60(0), 556-561 (2012).

18. S. M. Zain, N. E. A. Basri, H. Basri, N. Zakaria, R. Elfithri, M. Ahmad, K. G. Tiew, S. Zarina, Y. Sarifah, I. A. I. Khan, Focusing on Recycling Practice to Promote Sustainable Behavior. Procedia - Social and Behavioral Sci. 60(0), 546-555 (2012).

19. P. Viebahn, An environmental management model for universities: from environmental guidelines to staff involvement. J. Clean. Prod. 10(1), 3-12 (2002).

20. X. Chen, F. Lupi, G. He, J. Liu, Linking social norms to efficient conservation investment in payments for ecosystem services. Proceedings of the National Academy of Sci. 106(28), 1181211817 (2009).

21. D. Grazhdani, Assessing the variables affecting on the rate of solid waste generation and recycling: An empirical analysis in Prespa Park. Waste Manage. (2015).

22. S. F. Sidique, F. Lupi, S. V. Joshi, The effects of behavior and attitudes on drop-off recycling activities. Resour. Conserv. Recycl. 54(3), 163-170 (2010).

23. F. David, Strategic management. Columbus, OH: Merrill Publishing Company (1989).

24. Ministry of Housing and Local Government (MHLG). National Strategic Plan for Solid Waste Management in Malaysia: Volume 1 The Strategic Plan. Ministry of Housing and Local Government (2005b).

25. US Environmental Protection Agency, Wastes: resource conservation-reuse, recycle. Retrieved from

http://www.epa.gov/waste/conserve/rrr/recycle.htm. (2012).

26. A. Omran, A. Mahmood, H. Abdul Aziz, G. M. Robinson, Investigating households attitude toward recycling of solid waste in Malaysia: a case study. Int. J. Environ. Res., 3(2), 275-288 (2009).

27. J. C. Van den Bergh, Environmental regulation of households: An empirical review of economic and 
psychological factors. Ecol. Econ. 66(4), 559-574 (2008).

28. B. Bolaane, Constraints to promoting people centred approaches in recycling. Habitat Int. 30(4), 731-740 (2006).

29. M. Martin, I. D. Williams, M. Clark, Social, cultural and structural influences on household waste recycling: a case study. Resour. Conserv. Recycl. 48(4), 357-395 (2006).

30. T. C. Kinnaman, Policy watch: Examining the justification for residential recycling. J. Econ. Perspectives, 20(4), 219-232 (2006).

31. Envirowise, Increasing profits by reducing waste in managed shopping centres. Available at: www.envirowise.gov.uk (2002a).

32. P. J. H. van Beukering, T. R. Curlee, Managing a material world: Perspectives in industrial ecology. (Vellinga, P., Gupta, J., and Berkhout, F., Ed.). Dordrecht, Nertherlands: Kluwer Academic Publishers (1998).

33. S. M. Kassim, S. M. Ali, Solid waste collection by the private sector: Households' perspectiveFindings from a study in Dar es Salam city, Tanzania. Habitat Int. 30(4), 769-780 (2006).

34. MHLG, National Strategic Plan for Solid Waste Management in Malaysia: Volume 2 Main Report. Ministry of Housing and Local Government (2005c).

35. National Solid Waste Management Department (NSWMD), NSWMD Guidelines. Retrieved on 3 March, 2013 from http://www.kpkt.gov.my/jpspn_en/main.php?Conte $\mathrm{nt}=\operatorname{articles} \&$ ArticleID $=12 \& \mathrm{IID}=(2012)$.

36. C. Lakhan, Diversion, but at what cost? The economic challenges of recycling in Ontario. Resour. Conserv. Recycl. 95, 133-142 (2015).

37. S. Callan, J. Thomas, Economies of scale and scope: a cost analysis of municipal solid waste services. Land Econ. 77(4), 548-560 (2001).

38. O. Hernández, B. Rawlins, R. Schwartz, Voluntary recycling in Quito: factors associated with participation in a pilot programme. Environ. Urbanization 11(2), 145-160 (1999).

39. P. Carvalho, R. C. Marques, Economies of size and density in municipal solid waste recycling in Portugal. Waste Manage. 34(1), 12-20 (2014).

40. F. Murakami, A. Sulzbach, G. M. Pereira, M. Borchardt, M. A. Sellitto, How the Brazilian government can use public policies to induce recycling and still save money? J. Clean. Prod. 96, 94-101 (2015).

41. Y. J. Bor, Y.-L. Chien, E. Hsu, The marketincentive recycling system for waste packaging containers in Taiwan. Environ. Sci. Policy, 7(6), 509-523 (2004).

42. M. Abdul Jalil, Sustainable development in Malaysia: case study on household waste management. J. Sustain. Development, 3(3), 91102 (2010).

43. Z. Tarmudi, M. L. Abdullah, A. O. M. Tap, An overview of municipal solid wastes generation in Malaysia. Jurnal Teknologi. 51(1), 1-15 (2012).
44. T. K. Foo, Recycling of domestic waste: early experience in Singapore. Habitat Int. 21(3), 277289 (1997).

45. Y. Y. Ho, Recycling as a sustainable waste management strategy for Singapore: An investigation to find ways to promote Singaporean's household waste recycling behaviour. (Master-thesis). Lund University. Retrieved from http://www.lumes.lu.se/database/Alumni/01.02/thes es/ho_yanyin.pdf (2002).

46. M. Tongler, P. S. Phillips, A. D. Read, Using the theory of planned behaviour to investigate the determinants of recycling behaviour: a case study from Brixworth, UK. Resour. Conserv. Recycl. 42, 191-214 (2004).

47. G. Bel, X. Fageda, W. Warner, Is private production of public services cheaper than public production? A meta-regression analysis of solid waste and water services. J. Policy Analysis and Manage. 29(3), 553-577 (2010)..

48. S. E. Vergara, G. Tchobanoglous, Municipal solid waste and the environment: a global perspective. Annual Review of Environ. Resour. 37, 277-309 (2012).

49. D. C. Wilson, Development drivers for waste management. Waste Manage. Res. 25(3), 198-207 (2007).

50. P. Well, G. Bristow, P. Nieuwenhuis, T. B. Christensen, The role of academia in regional sustainability initiatives: Wales. J. Clean. Prod., 17(12), 1116-1122 (2009).

51. D. J. Eagan, J. Keniry, Green investment, green return: How practical conservation projects save millions on America's campuses. National Wildlife Federation, Washington, DC (1998).

52. S. H. Creighton, Greening the Lvory Tower. Importing the Environmental Track Record of Universities, Colleges, and Other Institutions. MIT Press, Cambridge, MA (1999).

53. Ministry of Education Malaysia, Institutions of higher education. Retrieved 27 October 2014, from http://www.moe.gov.my/v/ipta (2014).

54. J. W. Creswell, Research Design: Qualitative, Quantitative, and Mixed Methods Approaches (3rd ed.): SAGE Publications (2009).

55. Y. P. Chua, Mastering research methods. Malaysia: Mcgraw-Hill Education (2012).

56. W. P. Vogt, Quantitative research methods for professionals. United States: Pearson/Allyn and Bacon (2007).

57. Y. P. Chua, Mastering research statistics. Malaysia: McGraw-Hill Education (2013).

58. A. Field, Discovering statistics using SPSS (3rd ed.). London: SAGE Publications Ltd (2009).

59. H. K. T. Campos, Recycling in Brazil: Challenges and prospects. Resour. Conserv. Recycl. 85(0), 130-138 (2014).

60. M. R. Baharum, Recycling Initiatives in UK Shopping Centres, Factors Critical to Success. Unpublished $\mathrm{PhD}$, Liverpool John Moores University, Liverpool (2011). 